\title{
МОДУЛЬНЕ ФУНКЦІОНУВАННЯ АРХІТЕКТУРИ ІНФОРМАЦІЙНОЇ МЕДИЧНОЇ СИСТЕМИ ОХОРОНИ ЗДОРОВ'Я УКРАЇНИ
}

Л. В. Ільницька

\author{
Міжнародна академія медичної освіти
}

\begin{abstract}
У статті розглядається перспективний напрям аналізу модульного функціонування інсормаційної медичної системи. Прикладом формування базового шляху при визначенні внутрішніх механізмів упорядкування багаторівневої інфрормаційної структури є українська медична система «ЕМСІМЕД». Підхід до пошуку чіткого алгоритму модульного відтворення дозволяє обґрунтовано розкрити процес автоматизованої інтеграції на науково-технологічному рівні.
\end{abstract}

Ключові слова: модульне функціонування, архітектура інфрормаційної медичної системи.

\section{MODULATED FUNCTIONS OF THE ARCHITECTURE OF THE UKRAINIAN INFORMATION MEDICAL SYSTEM}

L. V. IInytska

\section{International Academy of Medical Education}

The article deals with the perspective direction of analysis of the modular functioning of the information medical system. An example of a basic approach in identifying internal mechanisms for streamlining the multilevel information structure is the Ukrainian medical system, known as «EMSIMED». The approach to finding a clear modular playback algorithm allows to reasonably disclosing the process of automated integration at the scientific and technological level.

Key words: modulated functioning, architecture of information medical system.

\section{МОДУЛЬНОЕ ФУНКЦИОНИРОВАНИЕ АРХИТЕКТУРЫ ИНФОРМАЦИОННОЙ МЕДИЦИНСКОЙ СИСТЕМЫ ЗДРАВООХРАНЕНИЯ УКРАИНЫ}

л. В. Ильницкая

\author{
Международная академия медицинского образования
}

\begin{abstract}
В статье рассматривается перспективное направление анализа модульного фрункционирования информационной медицинской системы. Примером выведения базового пути при определении внутренних механизмов упорядочивания многоуровневой иноормационной структуры является украинская медицинская система «ЭМСИМЕД». Подход к поиску чёткого алгоритма модульного отображения позволяет аргументировано раскрыть процесс автоматизированной интеграции на научно-технологическом уровне.
\end{abstract}

Ключевые слова: модульное фрункционирование, архитектура информационной медицинской системы. 
Вступ. Ускладнений процес розробки медичних інформаційних систем пов'язаний із певною специфікою маловивченого унікального технологічного процесу застосування на практиці відібраних теоретико-методологічних засад. Задля того, щоб позбавитися умовної вірогідності у встановленні деталізованих параметрів розробки науково-структурованого явища автоматизованої інформаційної моделі в системі охорони здоров'я, потрібно обIрунтувати вже набутий багаторічний вітчизняний досвід конкретизованого впровадження параметрів підвищеної ефективності по створенню інноваційного продукту.

Мета дослідження: відтворення цілісної, науково-технологічної основи діючих параметрів архітектури інформаційної медичної системи охорони здоров'я України в контексті авторської розробки функціонально-модульного впровадження.

Матеріали та методи дослідження. Дослідження базується на комплексній методології порівняльного обгрунтування та функціональної об’ єктивації представленої у тематиці.

Результати та їх обговорення. У структурній розробці постійної пошукової аналітики знаходяться дві медичні інформаційні системи. Це вже відомі на ринку науково-технічних інноваційних винаходів автоматизовані стратегічні платформи: «ЕМСІМЕД» та «Доктор Елекс» [5]. Обидві системи миттєво скоординовують інформаційні потоки щоденного та постійного запиту.

Ретельніше вивчаючи ці дві медичні розробки, $€$ можливість відпрацювати базові кроки послідовного моделювання цілісної складової по створенню базового комплексу наукової медичної інформації в Україні. Функціонально спільні зазначені інформаційні системи орієнтовного напряму пацієнто-лікарських електронних систем та майбутньої української бази даних наукової медичної інформації дозволяють чіткіше відтворити алгоритм автоматизованого контролю за специфічним медичним інформаційним навантаженням. Адже створення інформаційного відбору свідчить про органічно-цілісні супровідні дії по встановленню моделюючих чинників консолідації програмноідентифікаційних складників.

Відтак, послідовна конфігурація дотриманих науково-технологічних етапів допомагає також і у винайденні дотичних до медичної галузі обов'язкових прикладних завдань. Наприклад, при формулюванні нормативного переліку групи необхідних базових завдань щодо встановлення медичної інформаційної системи «Доктор Елекс» розробники, передусім, наголошують на дійсних перевагах цього медико-інформаційного нововведення. Отже, на фахову думку компетентного кола спеціалістів, саме така автоматизована інноваційна конструкція «дозволить швидко знаходити потрібну інформацію, структурує збереження медичних даних, впроваджує контроль за процесом лікування та підвищує якість обслуговування пацієнтів» [5].

Науковим девізом розробників нової системи $\epsilon$ налаштування власної роботи засадами «системної інтеграції». Цей супровідний вектор декларується сучасним підходом інформаційно-аналітичного забезпечення медичної галузі технологічними знахідками «розумного документообігу». Зрештою, універсальне, в даному разі винахідницьке інтеграційне зосередження спрямовується намаганнями якомога якісніше підійти до процесу «централізованого збереження інформації».

Разом із тим, медична інформаційна система «ЕМСIМЕД» є гарним прикладом розробки інтеграційного покращення опрацювання звичних документаційно-реєстраційних завдань медичних закладів за рахунок нагального введення інтенсивної програмної інформаційної автоматизації. Відтак, кардинальні зміни у роботі з професійною обробкою широкого спектру медичних даних дозволяють структурувати багатофункціональні інформаційні потоки, розвантажують персонал, оскільки полегшують координацію загальної планової роботи кожної окремої медичної установи.

Технологічні параметри запропонованої медичної системи «ЕМСIMЕД» підпорядковані структурному перерозподілу інформаційних потоків внутрішнього ресурсного призначення по модульним підрозділам, що відрізняються функціонально спрощеним інтерфейсом автоматизованої якості налаштування. Як зазначають автори цієї розробки: «завдяки своїй модульній структурі система в кожному окремому випадку конфігурується під конкретні потреби закладу і тому не потребує реорганізації бізнес-процесів» [5]. Зрештою, саме модульний підхід відрізняється інтегративним способом наслідування структурного розуміння призначення медичної інформаційної аналітики. Обов'язковість дотримання правил розбудови централізованого врівноваження відноситься до головного спрямування новоствореної системи - нести безумовну відповідальність стосовно підвищених вимог щодо процесу бездоганного захисту конфіденційних даних. Отже, «серед 
інших медичних інформаційних систем на ринку України «ЕМСІМЕД» як засіб автоматизації відрізняється зручною архітектурою, можливостями впровадження та супроводу, рівнем захисту даних та підтримкою інтеграції зі сторонніми продуктами» [5]. Врешті-решт, на прикладі українського інноваційно-програмного технологічного впровадження «ЕМСIMЕД» стає зрозумілим, що модульні рівні системної інтеграції інформаційної медичної розробки наділені особливим інструментарієм та виконують ролі самостійного автоматизованого контролю за відповідним полем системної інформаційної координації. Відтак, архітектурна розбудова модульної структури системи «ЕМСIMЕД» складається $з$ основного самостійного модуля широкої інформаційно-комунікаційної дії і додаткового, пов'язаного із телефонним сполученням, що дозволяє, зі свого боку, автоматизовано включати у роботу цієї досліджуваної системи SMSкомунікаційний режим профільних відправлень. Тобто за архітектурою інформаційно-аналітичного забезпечення системи охорони здоров'я України розробка «ЕМСІМЕД» $є$ двохмодульною. До першого модульного рівня медичної інформаційної системи «ЕМСIMЕД» відноситься вся площина первинних службових функцій - реєстраційних, адміністративно-управлінських та адміністративно-організаційних. Окреме місце відводиться статистичному супроводу цього модуля та функції архівації послідовно згрупованих організаційнокласифікаційним чином автоматично зібраних сегментів, що неабияк важливо для профільної медичної інформації.

При характеристиці функціонального призначення першого модуля слід звернути увагу, що інтегративним сполучником виступає саме показник автоматизованості. Оскільки ряд базових системно призначених позицій взаємопов'язано співпрацюють лише автоматизованим чином, це означає, що тільки засади перспективного програмного налаштування усієї інформаційної медичної системи дають умовивідну платформу для спільного планування та подальшого вдосконалення набутого креативного інформаційно-технологічного досвіду. Згідно із цим аспектом слід вказати наступний пояснювальний перелік функціональних характеристик медичної інформаційної системи «ЕМСIMЕД».

Реєстраційна функція системи автоматично опрацьовує основні реєстраційні завдання, допомагає спрощено обробляти вхідну інформацію.
Адміністративна функція спирається на «зручний і практичний інструмент, що дозволяє вирішити усі проблеми ведення документообігу та задачі його автоматизації в медзакладі».

Управлінсько-менеджментська функція автоматично виконує «процеси взаємодії, завдяки чому 3’являється можливість оцінювати ефективність та результативність роботи».

Функція контролю здебільшого допомагає в автоматизованому режимі виконувати процеси планування та ведення обліку.

Статистична функція «дозволяє користувачам системи збирати оперативну інформацію».

Функція архівації «автоматизує процес формування, архівації, пошуку та доступу» [5]. До цієї функції також належить і функція редагування надісланої інформації.

Практичність представленого шляху - унікальної медико-інформаційної архітектури - відповідає закладеним у цій розробці технічним нормам, де відзначається, що перевага надається функціональному налаштуванню модульних рівнів на технологічних позиціях системно-інтеграційного структурування [5].

Підтвердженням розпочатої стадії алгоритмізації дотримання модульних рівнів при створенні первинних ланок стосовно впровадження архітектурної модифікації інформаційної медичної структури є також архітектура інформаційної системи підтримки тестового контролю знань «LOGIT» [1]. Зокрема, український дослідник Р. М. Дубан зазначає, що фактично головним масштабним чинником при ефективному налаштуванні будь-якої інформаційної системи є «функціональна структура, елементами якої є основні модулі інформаційної системи, а зв'язками між елементами виступають потоки інформації» [1, с. 78]. Тобто передбачений розробниками функціонально-модульний перелік необхідних процесуальних розгалужених диспозицій буде відображатися і на загальному вигляді архітектури майбутньої науково-інформаційної медичної системи України. За Р. М. Дубаном, повний модульний перелік заздалегідь відзначених на стадії алгоритмізації системних функцій входить до вже іншої - наступної стадії програмного адміністрування інтегрованої модульної інформаційної цілісності з чіткими адресними, встановленими розробниками параметрами компетентнісного аналізу медичних службових даних.

Алгоритм проходження поетапної організації нового, іншого формату медичної інформації 
спирається на системно-структурний базис науково-технологічної діяльності. Стандартне розгорнуте бачення розвитку переформатованого впровадження лінійної послідовності необхідної динаміки відшліфованого обробленого інформаційного контексту логічно переходить від однієї стадії налаштування до іншої за рахунок передбаченого змісту алгоритмічного кваліфікованого планування. Тобто з одного процесу виринає інший - із етапу обробки медичної інформації, що важливо, автоматично розпочинається етап огляду, а потім йде плавний перехід до процесу системного накопичення.

Отже, Р. М. Дубан рекомендує застосовувати термін «модульна структура системи» [1]. У цій площині комплексного понятійного дискурсу існує певний перелік модульних моделей, системні пріоритети яких спираються на апаратну підтримку якісного програмного забезпечення. Структурний задум розміщення виокремлених моделей по необхідним ланкам поетапного зв'язку — саме цей процес відбувається із посиланням на зазначені рівні організаційно-адміністративного поступу. Відлуння такого напрямку науковотехнічних роздумів виявляє спрямований реєстр алгоритмічних кроків - органічної розбудови тих умовиводів, які ще утворилися на стадії формування концепції медичної інформаційної системи. Дотичні профілі підзвітних підсистем групуються у структурні моделі з функціональною прив'язкою виконання конкретизованих завдань медичного інформаційного навантаження. Такими багатосистемними значеннями автоматичного усвідомлення надання швидких наявних відповідей на нагальні запити володіють лише модульні структурні системи. Складний технічний арсенал базових дій здійснює найголовніший системний перехід від стану функціонального адміністрування, пов'язаного з етапом формування модульної мови систематизації інформаційних джерел, до стану оцінювання - у випадку з науковою медичною інформацією цей крок має складнішу конфігурацію та набуває вже іншого, профільного відтінку алгоритмічного оцінювання та системного накопичення.

Отже, до модульної структурної системи входять наступні модульні функціональні площини:

- модуль формування;

- модуль оцінювання;

- модуль апаратної підтримки;

- модуль адміністрування.
Якщо два перших модулі формують спільний системний інформаційний перехід конфігураційного впровадження організаційного впорядкування медичних даних, то решта модульних функціональних площин, а саме модуль апаратної підтримки та модуль адміністрування, не тільки доповнюють базовий інформаційний структурний комплекс, але й успішно відтворюють здатність до комплексної перевірки очікуваних результатів. Що найголовніше, «апаратна підтримка повинна мати вигляд простих спеціальних технічних засобів... що забезпечать потік інформації від респондента до бази даних» [1].

Модульний дороговказ, що виконує функцію адміністрування, фактично допомагає виконувати кроки по встановленню неперервного нагляду за інформаційною медичною системою в цілому. Тому що «модуль адміністрування має доступ до всіх інших модулів, що дає змогу адміністраторам та менеджерам інформаційної системи здійснювати контроль, технічну та функціональну підтримку» [1]. Риса нагального технічного супроводу за усією системою запрограмована на встановлення автоматизованого режиму безпеки - цей цілеспрямований інформаційно-комунікаційний намір внутрішнього та постійного контролю можливо надавати завдяки модулю адміністрування. Відтак, результат у вигляді текстового повідомлення стисло вказує на змодульований системою вектор самозгрупованої, тобто автоматично відтвореної функціональної ідентифікації, де незабаром отримана відповідь проходить повний замкнений безперервний модульний цикл.

Структурний каркас модульних зв'язків демонструє безперервність внутрішнього шляху відібраної медичної інформації, адже електронний рух згрупованих за вказаним користувачем потрібним контекстом конкретним діапазоном даних віддзеркалюється від модуля до модуля і виявляє явище повного системного циклу: запит - звернення, обробка - надходження. Зрештою, саме такий нагляд за відтворенням функціонального навантаження на професійні інноваційні медичні розробки розкриває інтегративний підхід до актуального вітчизняного винаходу — архітектурної структури наукової інформаційної медичної системи.

Проте, варто зауважити, що існує й інший тип модульної інформаційної регуляції - створення інформаційного медичного ресурсу за допомогою технології використання табличного процесора Excel. Так само варто зазначити, що утворений 
системний простір на існуючій базі з відповідними формотворчими елементами - це вже не циклічноінтеграційна система, а лінійно-множинна. Проте обидва представлених способи створення модульної інформаційної архітектурної конструкції мають спільну характеристику — завдяки налаштуванню функціонально-ідентифікаційного предикату автоматично встановлюються інформаційно-медичні пріоритети найактуальніших результатів, бо функція Excel полягає у створенні інтеграційного масиву внутрішнього адміністрування чітких інформаційних списків. Таким чином завдання по розпізнаванню інформаційної конфігурації виконується за системними списками в автоматичному режимі користування зведеною базою даних.

Саме «табличний процесор Excel розглядає таблицю введених особливих інформаційних даних як список, з яким можна здійснювати низку операцій» [4,с. 144] модульного зразка:

- сортування медичної інформації;

- фільтрацію медичної інформації.

Ці два функціональні режими модифікують інформаційний список за якостями важливих для користувачів наголосів, а саме: за найчастішим зверненням до скоординованих в ручному режимі записів. Тобто у даному разі відбувається розмежування існуючої площини інформаційного всезагального скупчення на оперативну медичну інформацію та однотипну медичну інформацію. Разом з тим, цей розподіл має функціональну основу виваженого впорядкування табличного формату. Спеціальний режим дотримання влучної перевірки створеного списку за типом даних вказує на характер встановлення модульних операцій, адже типізований реєстр автоматизованим чином відкидає непослідовну вірогідність, натомість нагальність централізованим гатунком надає встановленому списку неабияку корисну якість оперативного формату.

Отже, типізація запрограмованого модульного зразка відкриває можливості для налаштування стандартизованих форм автоматизованої надійності. Такі процеси, як сортування та фільтрація, ідентифікуються інформаційною системою на модульній основі самостійного входження до реєстративної форми базового встановлення. Відтак, завдяки вже цьому положенню, виявляються й інші багатозмістовні аспекти автоматизованої якості інформаційного середовища. Фактор стабільності - це по-особливому утримувана адміністративним чином рівновага бази даних, яка і надає користувачам повноцінного доступу з безперешкодним рухом до потрібної частини інформаційного джерела.

Створення базової ієрархії системно-інформаційного медичного осередку виявляє комплексність новітнього науково-технологічного потенціалу. Зрештою, інноваційні засади важливої присутності у структурі архітектури будь-якої інформаційної системи такого масштабного принципу, як комплексність, дозволяють розглядати функціональні складові технологічного процесу не окремо, а у сукупності згенерованих аналітичних позицій прикладного арсеналу взаємосумісності елементів системи. Зі свого боку, взаємосумісність спирається на вагомі характеристики автоматизованої сутності модульної функціональності. «Взаємосумісність тепер вважається основним фактором при створенні безпечного та надійного обміну медичними даними пацієнтів» [2, с. 14]. Інформаційний обмін та одержання запрограмованого результату — це влучне співставлення усіх модульних рівнів системи. Ресурсна підтримка кожної функціональної частини спільного стану оперативного налаштування єдиного сполучення в автоматизованому режимі технологічного узгодження приєднуються до алгоритмічного інформаційно-медичного комплексу. Алгоритм поступового зведення різносумісних елементів відбувається не відокремлено один від одного модуля обраного структурного рівня, а навпаки: з'єднання щільного абсолюту унеможливлює розбіжності у визначенні стратегічного рішення при отриманні результатів на виконання первинних функціональних завдань. Отже, така риса інформаційної медичної системи, як взаємосумісність, демонструє загальний стан розробленої наукової моделі, тому її наявність неможлива без автоматизованого процесу надійного забезпечення наведеної вище управлінсько-менеджментської функції безупинної взаємодії.

Розробникам архітектури наукової інформаційної медичної системи слід не забувати, що «однією з передумов розвитку взаємосумісності є розвиток стандартизації в медичній інформатиці» [2]. Життєва енергія модульного ритму залежить від наперед встановленого впорядкування. Циклічний рух, пов’ язаний із обробкою інформації, — це розпланований технологічно-методологічний традиційний шлях пошуку та обміну даними. Доцільна розбудова системи спирається на структурований ритм модульних взаємозв’ язків, архітектурна стратегія якої відрізняється тяжінням до нормованих 
стандартів. Як наголошує В. О. Качмар: «медичні інформаційні стандарти умовно можна розділити на дві групи: а) термінологічні стандарти; б) стандарти обміну інформацією» [2].

В основу термінологічних стандартів спеціалізованої медико-інформаційної системи покладені стабільно-незмінні знання у галузі лікувальної справи. Відкрита площина обігу медичними даними знаходиться у середовищі загальноприйнятих світових положень термінологічного зразка. Зокрема і обмін інформаційною звітністю, навіть у полі зору особливого алгоритмічного модульного встановлення, у будь-якому разі проходить крізь умовиводи стандартизованого медичного гатунку. Зібрані у чіткі групи конкретні понятійні утворення дозволяють легко орієнтуватися в інформаційній системі - проводити навігацію за пошуковим принципом типізованого, тобто стандартизованого способу дотримання міжнародних правил розподілу основного масиву медичної проблематики на позиціях наперед ухваленої рубрикації. Звичний вигляд пошукового вікна допомагає створити інформаційний запит, зрозумілий для користувача, але, що важливо, із стандартизовано укладеною пропозицією, задля того, щоб виявити потрібний інформаційний блок, розміщений за типізованою схемою організаційно-модульного впровадження. Відтак, лексичні одиниці медично-інформаційної систематизації демонструють шлях надходження вказаних у пошуковому запиті даних. Стандарти лінійно-графічної рубрикації теж полегшують входження до системних символів, позначок медичного лексичного рівня навігаційного процесу. Розроблена ієрархічна структура на основі обгрунтування проблемно-тематичної класифікації спрощує орієнтири при формулюванні запитів. Стратегія взаємосумісної стандартизації лексикографічного зразка дозволяє полегшувати роботу адміністративного чинника багатофункціонального ідентифікаційного модульного підпорядкування.

Навіть вузька експертна конкретизація опції спеціалізованого пошуку обумовлюється за принципом адміністративної належності взаємосумісними стандартами - шаблонами типізованої площини системної розробки інформаційно-медичної бази даних за миттєвим алгоритмічним визначенням індексовано укорінених значень. Медичний лексичний стандарт - це поступово створюваний світовий конгломерат уніфікованого англомовного термінологічного реєстру: «...рубрифікатор медичних термінів, розроблений Американською національною медичною бібліотекою, складається 3 набору термінів та їх опису. Цей стандарт $€$ найоб'ємнішою термінологічною системою, яка включає не тільки специфічні лабораторні та діагностичні терміни, а також і значну кількість ключових слів» [2]. Така стандартизована лексична структура унормованого канону є корисним ресурсним критерієм перевірки встановленої термінологічної класифікації при впровадженні архітектурної моделі української наукової медичної інформаційної системи.

Якщо окремо обговорювати принципи надійної довгострокової діяльності медико-інформаційної структури, то до другої групи медичних інформаційних стандартів традиційно відносять обмін медичною інформацією. У випадку системного обліку нетипізованого підходу до налаштування наукової медичної інформації слід наперед встановлювати видозмінюваний об'єктивний вектор міжмодульного обміну, існування якого пов'язане із остаточною стандартизацією фахової професійної обробки спеціалізованої медичної інформації. Зрештою, конкретизація механізмів нетипового пошуку поки що «використовується для індексації, каталогування та отримання доступу до світової медичної літератури» [2]. Отже, процес накопичення основної ресурсної інформаційної науковомедичної площини теж проходить запрограмовані, стандартизовані стадії налаштування навігаційнопошукового та адміністративно-організаційного сегментів потрібного безпечного функціонування системи у межах дотримання чітких параметрів модуля формування взаємосумісної конфігурації централізованої автоматизації.

Все ж таки, обмін медичною інформацією розроблюється за зразками надійного дотримання принципів укладання структурних взаємозв'язків, адже встановлений алгоритм розвитку системної інноваційності передбачає типізований взаємоузгоджений погляд на налаштування з'єднаних частин в єдиний комплекс автоматизованого проходження джерела інформації від модуля до модуля. Взаємосумісний сполучник полегшує здійснення режиму внутрішньої операційної комунікації між прихованими окремими частинами інформаційномодульної системи для надання спільного результату. Якість обміну інформаційними значеннями залежить від розуміння науково-технологічного типізованого зведення вітчизняними спеціалістами західних конструктивних підходів щодо введення головного алгоритму системного встановлення 
- саме цей вектор спільного, а отже і стандартного узгодження, зі свого боку, допомагає у проведенні «найважливіших глобальних індустріальних стандартів передачі та зберігання медичних зображень (рентген, МРТ, КТ, УЗД)» [2].

Зовнішня координація стосується взаємоузгодження наведених підстав для відпрацювання у експериментальному режимі певних форм стандартизованої взаємосумісності системних розгалужень, особливо цю обставину слушно згадати з приводу інколи різнорідного термінологічного навантаження. Проте, якщо спостерігати за західно-американським напрямком формування системної інформаційно-медичної всезагальної стандартизації, виявляється, що це пріоритетна зона координації відповідальних кваліфікованих інноваційних наукових лабораторій. «У США розробка стандартів медичної інформатики координується відповідними підкомітетами Американського національного інституту стандартизації ANSI» [2]. Отже, «розробка стандартів - це прерогатива держави. Поки не будуть прийняті стандарти для зберігання та передавання інформації, єдино правильним рішенням є розробка архітектури, орієнтованої на європейські стандарти» [2].

Стабільність модульної інформаційної регуляції відпрацьовується фахівцями на різних функціональних рівнях програмної розробки. Науковий аналіз розгалуженої структури інформаційної медичної системи вимагає відтворення взаємосумісних інтегративних модульних рівнів, шлях яких оприлюднюється у певних теоретичних класифікаціях. Існування «структурно-функціональної взаємодії» та «функціонально-організаційної моделі» інформаційно-аналітичних вимірів медичного спрямування дозволяє відзначити нерегламентовані методологічні та технологічні протиріччя та прискорити отримання бажаного ефекту від бездоганної діяльності вказаної системи.

Вітчизняний дослідник Є. М. Кривенко [3] пропонує провести класифікаційно-функціональний перелік найсуттєвіших завдань при впровадженні у життя змістовної архітектурної організації інформаційної медичної системи України. Ця розробка за новими сучасними вимогами має автоматично виконувати такі дії:

- збір інформації;

- аналіз отриманих даних;

• отримання узагальненої інформації в електронній формі;
- проведення інформаційного аналізу одержаних результатів;

- порівняння результатів 3 існуючими стандартами;

- виявлення відхилення при подачі інформації [3]. Цей перелік демонструє стратегію органічного співіснування декількох функціональних механізмів виконання. Слушно вказати на той факт, що паралельно цей список процесуальних, багатоступеневих кроків стає також і арсеналом по відтворенню структурної шкали функціонального налаштування. Тобто це підхід, у якому чергуються операційні кроки від найзагальнішого - збору інформації до включення адміністративного модуля, за допомогою якого зафіксовуються не просто наявні відхилення, а й причини розбіжностей та надаються користувачу швидкі способи усунення проблеми. Разом з тим, Є. М. Кривенко стверджує, що ця консолідація структурно-функціонального руху медичних даних отримує видове призначення, за яким відбувається типологізація зведеного, систематизованого інформаційного результату. Цей видовий реєстр оцінювання технологічного функціонування розробленого ресурсу вже у межах архітектури медичної інформаційної системи зводиться до двох форм:

1) поточна медична інформація;

2) планова медична інформація [3].

Обидві перераховані форми структурно організовані в інтеграційний системний простір, який має наукову назву «достовірна комплексна інформація» медично-інформаційного способу функціонального моделювання. При окремому науковому 3’ясуванні значення достовірності слід звернути увагу на якісне проходження запиту користувача по структурній шкалі функціонального налаштування — саме тоді автоматично утворюється достовірний зміст отриманого інформаційного медичного повідомлення. Разом з тим, розуміння розширеного фактору багатоступеневої комплексності може бути в інтеграційній структурі автоматизованої цілісності досліджуваної системи перегруповане на лаконічний функціональний поступовий тривекторний шлях: «структура, процес, результат» [3].

Висновки. Об’ємність тривалого алгоритмічного малюнку відтворює багатолінійну поліаспектність системного хронометражу автоматизації. Безпосередня дієвість архітектурного впорядкування тримається на інтегративній систематизації аналітичного базису 
комплексних науково-методологічних пропозицій. Функціональна приналежність взаємних еквівалентів співпадає із згрупованою модульністю. Структура, процес, результат - ці напрямки алгоритмічного руху відкривають інноваційний резонанс до доцільного впровадження інформаційної медичної системи. Якісні показники відповідного зваженого технологічного розкриття поставленого завдання вдосконалюють підпорядковані функції багатоступеневої структури. Апробація ресурсного

\section{Література:}

1. Дубан Р. М. Архітектура інформаційної системи підтримки тестового контролю знань «Logit» / Р. М. Дубан // Актуальні проблеми автоматизації та інформаційних технологій. — 2011. - Т. 15. C. 77-86.

2. Качмар В. О. Медичні інформаційні системи - стан розвитку в Україні / В. О. Качмар // Український журнал телемедицини та медичної телематики. 2010. - T. 8, № 1. - С. 12-17.

3. Кривенко Є. М. Сучасна структура функціонально-організаційної моделі інформатизації охорони здоров’я на регіональному рівні / Є. М. Кривенко // Україна. Здоров’я нації. — 2014. — № 2. — С. 75-82.

4. Медична інформатика в модулях / I. Є. Булах, Л. П. Войтенко, М. Р. Мруга [та ін]. - К. : ВСВ «Медицина», 2012. - 208 с.

5. Що таке «ЕМСIMЕД» для керівника медичного закладу? - [Електронний ресурс] Режим доступу: http://tg.ck.ua/\%D0\%BC\%D1\%81\%D0\%BC\%D0\%B5\%D0\%B4/. потенціалу модульного призначення базується на автоматизованих взаємозв’язках — це прикладна структурна шкала функціонального налаштування. Механізми проведення стандартизації врівноваженого моделювання окреслюють життєву потребу інфраструктурного позиціонування державницької програми по оснащенню медичних закладів України інформаційними системами надсучасного рівня.

\section{References.}

1. Duban, R. M. (2011). Arkhitektura informatsiinoi sistemi pidtrimki testovogo kontrolyu znan' «Logit» [The architecture of the information system for the support of the test knowledge control «Logit»]. Aktual'ni problemi avtomatizatsii ta informatsiinikh tekhnologii (Problems of Automation and Information Technologies), 15, 77-86 [In Ukrainian].

2. Kachmar, V. O. (2010). Medichni informatsiini sistemi - stan rozvitku v Ukraini [Medical information systems - the state of development of Ukraine]. Ukrains'kii zhurnal telemeditsini ta medichnoi telematiki (Ukrainian Journal of Telemedicine and Medical Telematics), 8(1), 12-17 [In Ukrainian].

3. Krivenko, E. M. (2014). Suchasna struktura funktsional'no-organizatsiinoi modeli informatizatsiï okhoroni zdorov'ya na regional'nomu rivni [Modern structure of the functional and organizational model of health informatization at the regional level]. Ukraina. Zdorov’ya natsii (Ukraine. Health of Nation), 2, 75-82 [In Ukrainian].

4. Bulakh, I. E., Voitenko, L. P., Mruga, M. R., Alita, O. S., Zhegrii, T. I., \& Krivenko, I. P. (2012). Medichna informatika v modulyakh [Medical Informatics in Modules]. Kyiv: Meditsina (Medicine) [In Ukrainian].

5. Shcho take «EMSIMED» dlya kerivnika medichnogo zakladu? [What is "EMSIMED» for the head of the medical institution?] Retrieved from: http://tg.ck. ua/\%D0\%BC\%D1\%81-\%D0\%BC\%D0\%B5\%D0\%B4/ [In Ukrainian]. 